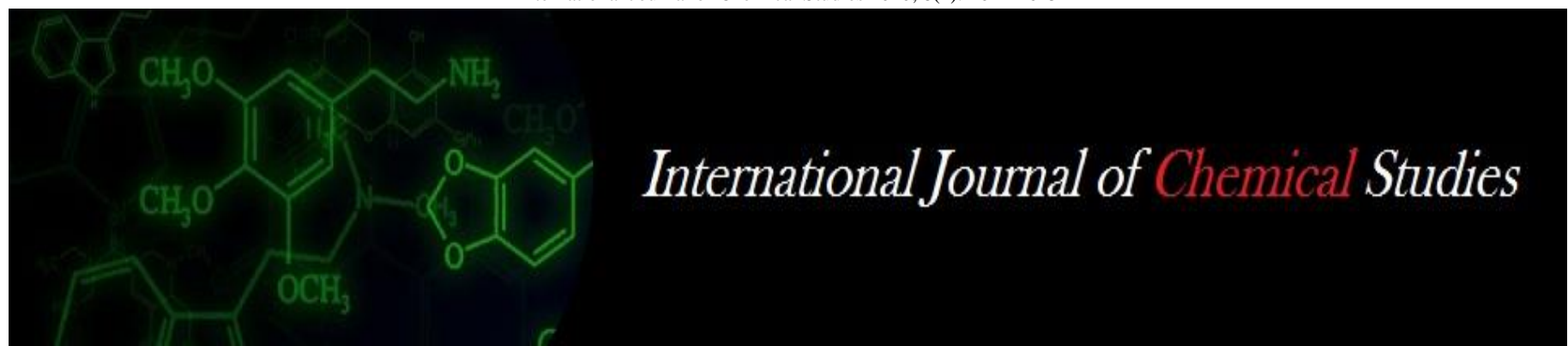

P-ISSN: 2349-8528

E-ISSN: 2321-4902

IJCS 2020; 8(1): 1641-1645

(C) 2020 IJCS

Received: 07-11-2019

Accepted: 09-12-2019

Venkataravana Nayaka GV Ph.D. Scholar, Department of Agronomy, S.V. Agricultural College, Tirupati, ANGRAU, Andhra Pradesh, India

Prabhakara Reddy G Professor and Farm Superintendent, Department of Agronomy, S.V. Agricultural College, Tirupati, Andhra Pradesh, India

Mahendra Kumar R Principal Scientist, Department of Agronomy, ICAR-Indian Institute of Rice Research, Hyderabad, Telangana, India
Corresponding Author: Venkataravana Nayaka GV Ph.D. Scholar, Department of Agronomy, S.V. Agricultural College, Tirupati, ANGRAU, Andhra Pradesh, India

\section{Dry matter production and accumulation in different plant parts of rice cultivars as influenced by irrigation regimes and systems of cultivation}

\author{
Venkataravana Nayaka GV, Prabhakara Reddy G and Mahendra Kumar R
}

DOI: $\underline{\text { https://doi.org/10.22271/chemi.2020.v8.i1x.8498 }}$

\begin{abstract}
Alternate wetting and drying (AWD) irrigation has been widely adopted to replace continuous flooding (CF) irrigation for saving water and increasing water productivity in irrigated rice systems. There is limited information on the performance of different rice cultivars under different establishment methods. A field experiment was conducted on a clay loam soil at Indian Institute of Rice Research (IIRR) formerly Directorate of Rice Research (DRR), Rajendranagar, Hyderabad, Telangana during the kharif seasons of 2017 and 2018. to study the "productivity and water use efficiency of rice cultivars under different irrigation regimes and systems of cultivation" The treatments consisted of two irrigation regimes Alternate wetting and drying and Saturation as main plot treatments, three establishment methods System of Rice Intensification (SRI), Drum Seeding (DS) and Normal transplanting (NTP) as sub plot treatments and four Cultivars namely DRR Dhan 42, DRR Dhan 43, MTU-1010 and NLR34449 as sub-sub plot treatments summing up to 24 treatment combinations laid out in split-split plot design with three replications. Among the cultivars, DRR Dhan 43 registered higher dry matter production at 90 DAS/DAT and harvest as compared to other cultivars. Whereas MTU-1010 and NLR34449 recorded on par dry matter production values at all the crop growth stages during both the years of study. However DRR Dhan 42 produced the lowest dry matter production compared to other genotypes. DRR Dhan 43 recorded higher dry matter accumulation $\left(\mathrm{g} \mathrm{m}^{-2}\right)$ in root, stem and leaves at all the crop growth stages, during both the years of the study over other cultivars.
\end{abstract}

Keywords: Rice, cultivars, dry matter production and accumulation, irrigation regimes and systems of cultivation

\section{Introduction}

Rice is one of the most important cereal crops occupying second position in global agriculture and it is widely grown in India due to its wider adaptability. To safeguard and sustain the food security in India, it is quite important to increase the productivity of rice under limited resources, especially land and water. Hence, the major challenges are to produce more rice per unit amount of natural resource. As per the concepts of water foot print and virtual water to produce one $\mathrm{kg}$ of rice 3000 to 5000 litres of water is required. Being a water-intensive crop, cultivation of rice has been a big drain on water resources. Rice is a heavy water consumer but water for rice production is becoming scarce and expensive due to the increased demand for water from the ever growing population and industries (Choudhury et al., 2014) ${ }^{[4]}$. Rainfall patterns in many areas are becoming more unreliable, with extremes of drought and flooding occurring at unexpected time. Traditional planting has been the most important and common method of crop establishment practice under irrigated lowland rice ecosystems in tropical Asia. In irrigated lowland rice which not only consumes more water but also causes wastage of water resulting in degradation of land. In recent years to tackle this problem, many methods of cultivation have been developed and one among them is System of Rice Intensification (SRI). Growth and yield characteristics of any cultivar depend on genetic and environmental factors. Among the different production factors, varietal selection at any location plays an important role. Proper crop management depends on the growth characteristics of various varieties to get maximum benefit from new genetic material. Among the different water-saving irrigation methods in rice, the most widely adopted is alternate wetting and drying (AWD). 
Many of the rice cultivars vary in their performance under different systems of cultivation. Higher dry matter production per unit area is the critical prerequisite for higher yield. The amount of dry matter production partitioning depends on effective photosynthesis and respiration of crop. The total yield of dry matter is the total amount of dry matter produced and less the photosynthates used for respiration. Finally, the manner in which the net dry matter produced is distributed among the different parts of the plant, which determine magnitude of the economic yield (Arnon, 1972) ${ }^{[3]}$. There was a progressive and conspicuous increase in root, stem and leaf dry matter accumulation $\left(\mathrm{g} \mathrm{m}^{-2}\right)$ with the advancement of crop growth stage up to 90 DAT.

\section{Material and Methods}

The field experiment comprises of 24 treatment combinations conducted at Indian Institute of Rice Research (IIRR) formerly Directorate of Rice Research (DRR) farm, Rajendranagar, Hyderabad during the kharif seasons of 2017 and 2018. located at $17^{\circ} 19^{\prime} \mathrm{N}$ latitude, $78^{\circ} 23^{\prime}$ E longitude and an altitude of $542.3 \mathrm{~m}$ above mean sea level, It represents the Southern Telangana agro-climatic zone of Telangana state. According to Troll's climatic classification, it falls under semi-arid tropics (SAT). During the crop growth period, a total rainfall of $990.4 \mathrm{~mm}$ was received in 50 rainy days in the first year and $375.6 \mathrm{~mm}$ in 26 rainy days in the second year. The weekly mean maximum and minimum temperature on an average of $30.4{ }^{0} \mathrm{C}, 31.2{ }^{0} \mathrm{C}$ and $19.9{ }^{\circ} \mathrm{C}, 18.2{ }^{\circ} \mathrm{C}$ were recorded during 2017 and 2018 respectively. The treatments consisted of two irrigation regimes Alternate wetting and drying and Saturation as main plot treatments, three establishment methods System of Rice Intensification (SRI) with spacing of $25 \mathrm{~cm} \times 25 \mathrm{~cm}$, Drum Seeding (DS) with spacing of $20 \mathrm{~cm} \times 10 \mathrm{~cm}$ and Normal transplanting (NTP) with spacing of $20 \mathrm{~cm} \times 15 \mathrm{~cm}$ as sub plot treatments and four Cultivars namely DRR Dhan 42, DRR Dhan 43, MTU-1010 and NLR-34449 as sub-sub plot treatments laid out in splitsplit plot design with three replications. The area of each gross plot was $7 \times 3 \mathrm{~m}^{2}$. Seedlings were transplanted with an average of one seedling per hill in the SRI method of planting. FYM at @ $10 \mathrm{t} \mathrm{ha}^{-1}$ was uniformly applied to all the plots before final puddling and levelling. The recommended dose of phosphorus @ $60 \mathrm{~kg} \mathrm{P}_{2} \mathrm{O}_{5} \mathrm{~kg} \mathrm{ha}^{-1}$ as single super phosphate (SSP) was applied to all the treatments uniformly as basal and potassium @ $40 \mathrm{~kg} \mathrm{~K}_{2} \mathrm{O} \mathrm{ha}{ }^{-1}$ as muriate of potash (MOP) was applied in two splits, 75 per cent as basal and the remaining 25 per cent at 75 DAS/DAT. Recommended dose of nitrogen $\left(120 \mathrm{~kg} \mathrm{ha}^{-1}\right)$ was applied through urea in three splits, 50 per cent as basal, 25 per cent at 50 DAS/DAT and the remaining 25 per cent at 75 DAS/DAT.

\section{Results and Discussion}

Effect on dry matter production and accumulation

Increase in average total dry matter production of rice was rather slow up to 30 DAS there after it increased linearly up to 90 DAS and further, it continued to increase until maturity but it was at a diminishing rate in both the years of study (Table.1 and Fig.1) there was a Progressive increase in dry matter accumulation $\left(\mathrm{g} \mathrm{m}^{-2}\right)$ in different plant parts viz.. root, stem and leaves with the advancement of crop growth stage up to 90 DAS/DAT (Fig.2).

Table 1: Dry matter production of rice as influenced by different irrigation regimes, systems of rice cultivation and cultivars during kharif 2017 and 2018

\begin{tabular}{|c|c|c|c|c|c|c|c|c|c|c|c|c|}
\hline \multirow{3}{*}{ Treatments } & \multicolumn{12}{|c|}{ Dry matter production $\left(\mathrm{Kg} \mathrm{ha}^{-1}\right)$} \\
\hline & \multicolumn{3}{|c|}{30 DAS/DAT } & \multicolumn{3}{|c|}{60 DAS/DAT } & \multicolumn{3}{|c|}{90 DAS/DAT } & \multicolumn{3}{|c|}{ At harvest } \\
\hline & 2017 & 2018 & Pooled & 2017 & 2018 & Pooled & 2017 & 2018 & Pooled & 2017 & 2018 & Pooled \\
\hline \multicolumn{13}{|c|}{ Irrigation regimes (I) } \\
\hline $\mathrm{I}_{1}: \mathrm{AWD}$ & 198 & 204 & 201 & 601 & 620 & 611 & 4209 & 4343 & 4276 & 11022 & 11373 & 11198 \\
\hline $\mathrm{I}_{2}:$ Saturation & 196 & 185 & 191 & 555 & 559 & 557 & 3864 & 3932 & 3898 & 10164 & 10327 & 10246 \\
\hline $\mathrm{SEm} \pm$ & 2.2 & 3.1 & 2.6 & 14.1 & 19.5 & 16.8 & 117.9 & 135.6 & 126.7 & 290.8 & 315.3 & 303.0 \\
\hline C.D $(\mathrm{P}=0.05)$ & NS & NS & NS & 41 & 58 & 50 & 342 & 407 & 375 & 855 & 986 & 921 \\
\hline \multicolumn{13}{|c|}{ Systems of rice cultivation $(\mathrm{S})$} \\
\hline $\mathrm{S}_{1}: \mathrm{SRI}$ & 207 & 225 & 215 & 621 & 682 & 651 & 4348 & 4779 & 4564 & 11385 & 12514 & 11950 \\
\hline $\mathrm{S}_{2}: \mathrm{DS}$ & 202 & 192 & 197 & 613 & 583 & 598 & 4293 & 4086 & 4190 & 10242 & 10700 & 10971 \\
\hline $\mathrm{S}_{3}: \mathrm{NTP}$ & 184 & 168 & 176 & 560 & 509 & 534 & 3921 & 3565 & 3743 & 9270 & 9337 & 9803 \\
\hline SEm \pm & 5.6 & 6.9 & 5.7 & 17.2 & 20.9 & 17.4 & 120.6 & 146.7 & 122.3 & 315.8 & 384.3 & 320.2 \\
\hline C.D $(P=0.05)$ & 18 & 22 & 19 & 56 & 68 & 56 & 393 & 478 & 398 & 1029 & 1036 & 1044 \\
\hline \multicolumn{13}{|c|}{ Cultivars (C) } \\
\hline $\mathrm{C}_{1}$ : DRR Dhan 42 & 183 & 185 & 184 & 556 & 541 & 548 & 3892 & 4044 & 3968 & 9193 & 9851 & 9522 \\
\hline $\mathrm{C}_{2}$ : DRR Dhan 43 & 205 & 198 & 201 & 603 & 612 & 607 & 4364 & 4276 & 4320 & 11427 & 11670 & 11548 \\
\hline $\mathrm{C}_{3}: \mathrm{MTU}-1010$ & 195 & 186 & 190 & 601 & 563 & 582 & 4351 & 3945 & 4148 & 10948 & 11150 & 11049 \\
\hline $\mathrm{C}_{4}:$ NLR-34449 & 190 & 187 & 188 & 571 & 580 & 575 & 4142 & 4111 & 4126 & 11394 & 10330 & 10862 \\
\hline $\mathrm{SEm} \pm$ & 6.0 & 5.2 & 4.5 & 18.2 & 15.7 & 13.7 & 127.5 & 110.4 & 96.1 & 334.0 & 289.3 & 251.6 \\
\hline C.D $(\mathrm{P}=0.05)$ & 17 & 14 & 12 & 51 & 44 & 39 & 362 & 314 & 273 & 949 & 823 & 886 \\
\hline Interactions & NS & NS & NS & NS & NS & NS & NS & NS & NS & NS & NS & NS \\
\hline
\end{tabular}

\section{Effect of irrigation regimes}

Alternative wetting and drying method of irrigation recorded significantly higher DMP at all the growth stages of rice (60, 90 DAS/DAT and at harvest) except at 30 DAS/DAT during both 2017 and 2018 as compared to saturation. The dry matter production in AWD was 601 and $620 \mathrm{~kg} \mathrm{ha}^{-1}$ at $60 \mathrm{DAS} / \mathrm{DAT}$, 4209 and $4343 \mathrm{~kg} \mathrm{ha}^{-1}$ at 90 DAS/DAT and 11022 and 11373 $\mathrm{kg} \mathrm{ha}^{-1}$ at harvest during 2017 and 2018 respectively as compared to saturation was 555 and $559 \mathrm{~kg} \mathrm{ha}^{-1}$ at 60
DAS/DAT, 3864 and $3932 \mathrm{~kg} \mathrm{ha}^{-1}$ at 90 DAS/DAT and 10164 and $10327 \mathrm{~kg} \mathrm{ha}^{-1}$ at harvest during 2017 and 2018 respectively (Table 1 and Fig.1). It is because of rapid growth by maintenance of adequate wetness with intermittent water to crop that maintained good plant roots and varied metabolic processes that perform higher nutrient mobilization. These results were also in line with the observations made by Lu et al. (2000) ${ }^{[8]}$, Kumar et al. (2013) ${ }^{[7]}$ and Chowdhury et al. (2014) ${ }^{[4]}$. 
There was no significant difference in dry matter accumulation $\left(\mathrm{g} \mathrm{m}^{-2}\right)$ of root, stem and leaves among the irrigation regimes during both the years of study (Fig. 2). Relatively higher dry matter accumulation $\left(\mathrm{g} \mathrm{m}^{-2}\right)$ of root was observed in AWD at 30, 60, 90 DAS and harvest during the both years. It might be due to increased root oxidation activity and root source cytokinins in intermediate irrigation in AWD. This finding was in conformity with the findings of Armstrong and Webb (1985) ${ }^{[2]}$, who observed the possibility of extended growth of rice roots under influence of oxygen.

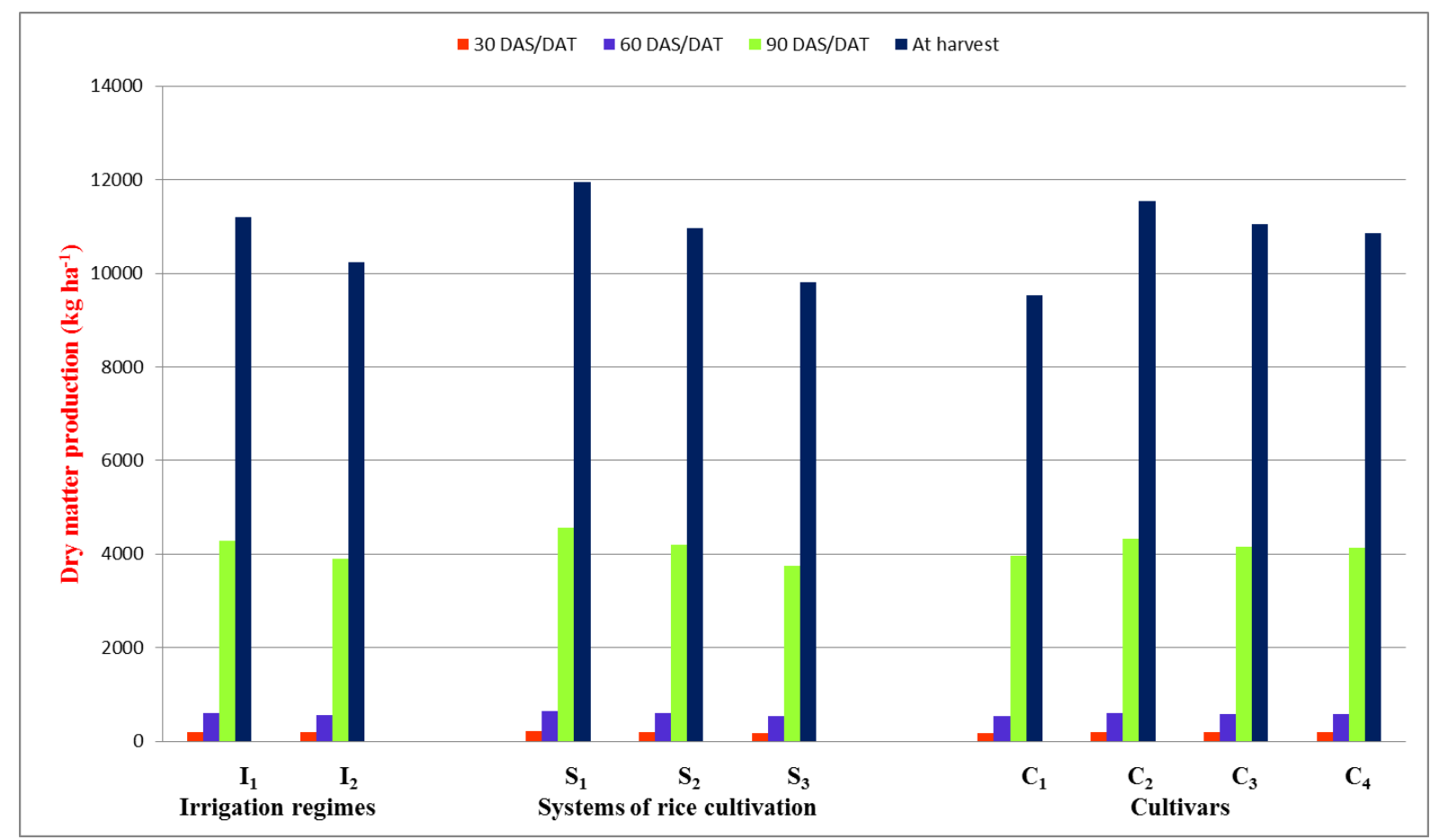

Fig 1: Dry matter production $\left(\mathrm{kg} \mathrm{ha}^{-1}\right)$ of rice as influenced by different irrigation regimes, systems of rice Cultivation and cultivars (pooled means of kharif 2017 and 2018)

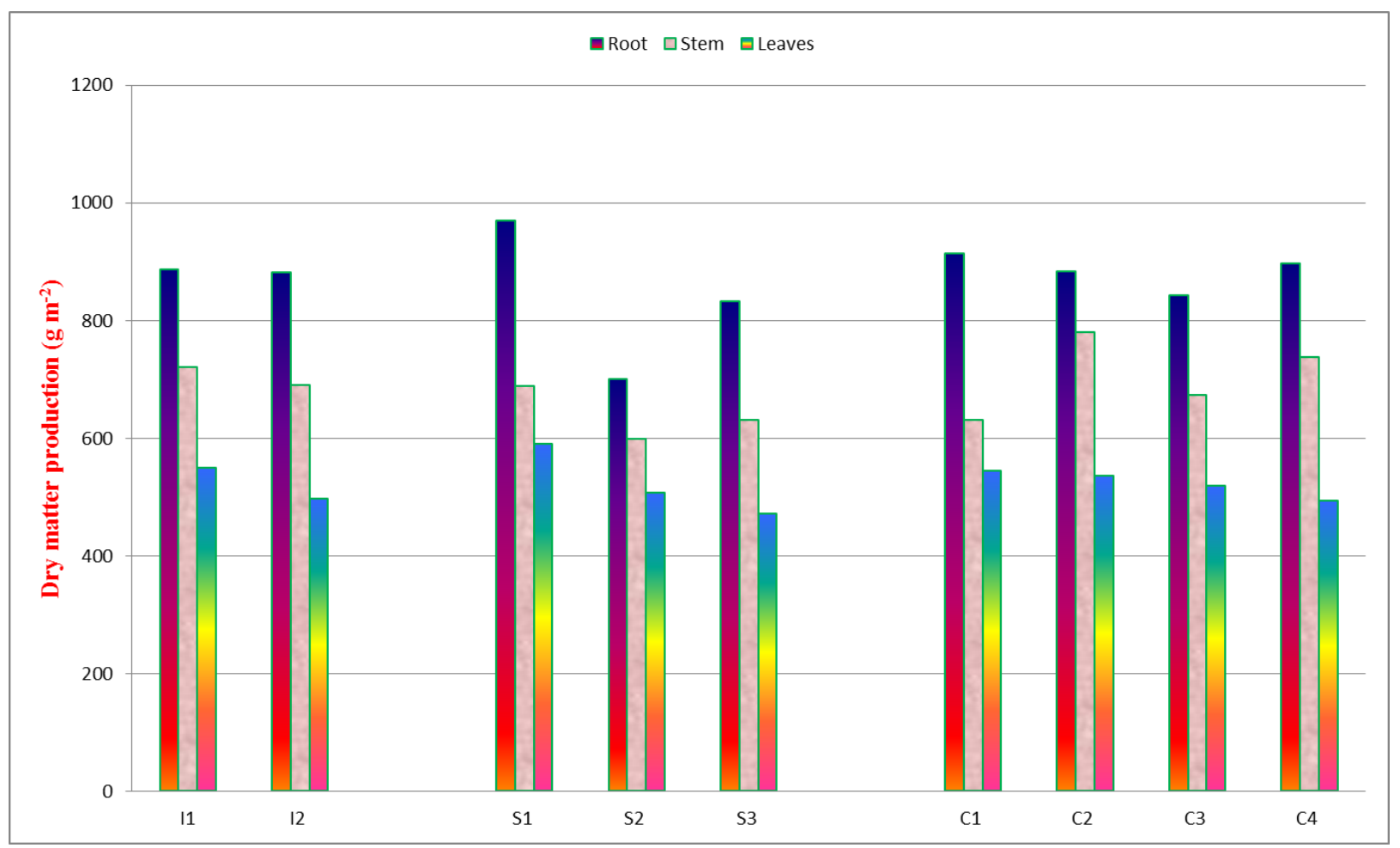

Fig 2: Dry matter production $\left(\mathrm{g} \mathrm{m}^{-2}\right)$ and partitioning in rice as influenced by different irrigation regimes, establishment methods and cultivars (pooled means of Kharif 2017 and 2018)

\section{Effect of systems of cultivation}

Among the different systems of rice cultivation, SRI recorded significantly higher DMP as compared to normal transplanting, however it was comparably at par with drum seeding at all the growth stages. Significantly the higher DMP was noticed in SRI at 30,60, 90 DAS/DAT and at harvest $\left(215,651,4564\right.$ and $11950 \mathrm{~kg} \mathrm{ha}^{-1}$ respectively in pooled means of both 2017 and 2018) as compared to normal transplanting (176, 534, 3743 and $9803 \mathrm{~kg} \mathrm{ha}^{-1}$ respectively in pooled means of both 2017 and 2018) and it was at par with 
drum seeding (197, 598, 4190 and $10971 \mathrm{~kg} \mathrm{ha}^{-1}$ respectively in pooled means of both 2017 and 2018) (Table.1 and Fig.1). Higher dry matter production of the above treatment may be attributed to better establishment of seedlings and more number of tillers $\mathrm{m}^{-2}$. Significantly lower dry matter was recorded with drum seeding at all the stages except at 30 DAS. Lowest dry matter production in drum seeding method may be attributed to non- uniform plant stand and less number of tillers $\mathrm{m}^{-2}$. This was supported by Anbumani et al. (2004) [1]. The higher dry matter production in SRI method was attributed to planting of young seedling at shallow depth in wider spacing and cono-weeding which leads to taller plants, higher leaf area, better root growth, profuse and strong tillers with higher crop growth rate. Increased shoot: root ratio and production of more number of tillers hill ${ }^{-1}$ under wider spacing were the reasons for increased dry matter production (Rajesh and Thanunathan, 2003) ${ }^{[11]}$. In addition to that conoweeding increased the soil aeration which enhanced availability of dissolved oxygen in irrigation water thereby increasing shoot: root ratio and LAI and subsequently increasing dry matter production (Uphoff, 2002) ${ }^{[15]}$. The results obtained in this investigation are in conformity with the findings of Hussain et al. (2012) [5], Sridevi and Chellamuthu (2012) ${ }^{[14]}$ and Rajendran et al. (2013) ${ }^{[10]}$.

Dry matter accumulation in different plant parts was superior with system of rice intensification over drum seeding and NTP during both the years of study at all the growth stages (Fig. 3). Less interplant competition would have enabled the plants to have more physiological activity. In square planting with wider spacing more soil area was available for foraging thus leading to improved root growth in SRI. This is in accordance with the observations of Jayakumar et al. (2005) [6], Priyanka et al. (2013) ${ }^{[9]}$ and Rani and Sukumari (2013) [12].
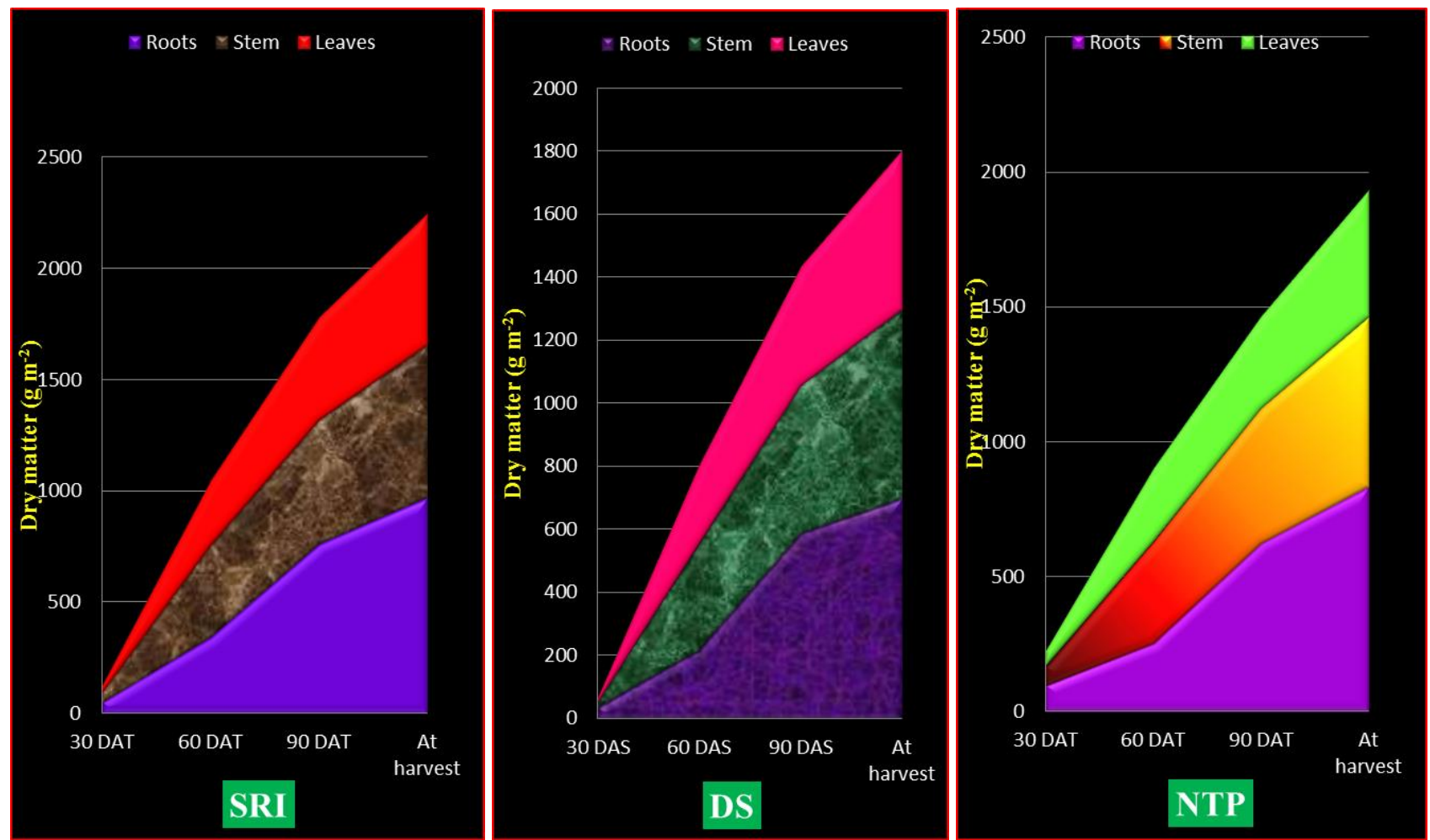

Fig 3: Comparison between the dry matter production and partitioning at different growth stages into root, stem and leaf under SRI, DS and NTP methods (pooled means of Kharif 2017 and 2018)

\section{Effect of rice Cultivars}

Among the different varieties, DRR Dhan 43 cultivar recorded significantly higher dry matter production at 30 DAS/DAT (205, 198 and $201 \mathrm{~kg} \mathrm{ha}^{-1}$ during 2017, 2018 and in pooled means, respectively) over other cultivars. However MTU-1010 cultivar was at par with DRR Dhan 43 at 30 DAS/DAT. At 60, 90 DAS/DAT and harvest significantly DMP was recorded with DRR Dhan 43 cultivar $(607,4320$ and $11548 \mathrm{~kg} \mathrm{ha}^{-1}$ respectively in pooled means of both 2017 and 2018) than other cultivars. However MTU-1010 and NLR-34449 cultivars were recorded on par DMP values with DRR Dhan 43. While DRR Dhan 42 cultivar recorded the lowest DMP compared to other cultivars at all the growth stages during 2017 and 2018. difference in DMP among the cultivars and the lower values of DRR Dhan 42 may be due to genetical inherent character of the varieties. Similar findings were also line up with Sharath (2017) ${ }^{[13]}$ and Vijay (2018) ${ }^{[16]}$. Among the cultivars, dry matter accumulation $\left(\mathrm{g} \mathrm{m}^{-2)}\right.$ in root, stem and leaves at all the crop growth stages in both the years of study and in pooled means was statistically non-significant except DRR Dhan 43 where recorded significantly higher dry matter accumulation $\left(\mathrm{g} \mathrm{m}^{-2}\right)$ during both the years of the study over other cultivars.

\section{Effect of interaction}

The interaction was statistically non significant among irrigation regimes, systems of rice cultivation and rice cultivars on dry matter production and accumulation at all the growth stages during both the years of study.

\section{Conclusion}

Results revealed that the increase in average total dry matter production of rice was rather slow up to 30 DAS there after it increased linearly up to 90 DAS and further, it continued to increase until maturity but it was at a diminishing rate in both the years of study. There was progressive increase in dry matter accumulation $\left(\mathrm{g} \mathrm{m}^{-2}\right)$ in different plant parts viz.. root, stem and leaves with the advancement of crop growth stage 
up to 90 DAS/DAT under semi arid tropical climatic condition in clay loam soil at Indian Institute of Rice Research (IIRR), Rajendra nagar, Hyderabad.

\section{Reference}

1. Anbumani S, Chandrasekharan B, Kuppuswamy G. Evaluation of establishment methods and NPK levels in rice and their impact on succeeding crop. Agricultural Science Digest. 2004; 24(3):190-193.

2. Armstrong W, Weeb T. A critical oxygen pressure for root extension in rice. Journal of Experimental Botany. 1985; 36:1573-1582.

3. Arnon I. Crop production in dry regions. International Textbook Company Limited, London, 1972, 284.

4. Chowdhury MR, Kumar V, Sattar A, Brahmachari K. Studies on the water use efficiency and nutrient uptake by rice under System of Intensification. The Bio scan. 2014; 9(1):85-88.

5. Hussain A, Bhat MA, Ganie MA. Effect of number and age of seedlings on growth, yield, nutrient uptake and economics of rice (Oryza sativa) under system of rice intensification in temperate conditions. Indian Journal of Agronomy. 2012; 57(2):133-137.

6. Jayakuamr B, Subathra C, Velu V, Ramanathan S. Effect of integrated crop management practice on rice (Oryza sativa L.) root volume and rhizosphere redox potential. Journal of Agronomy. 2005; 4(4):311-314.

7. Kumar S, Singh RS, Yadav L, Kumar K. Effect of moisture regime and integrated nutrient supply on growth, yield and economics of transplanted rice. Oryza. 2013; 50(2):189-191.

8. Lu J, Ookawa T, Hirasawa T. The effects of irrigation regimes on the water use, dry matter production and physiological responses of paddy rice. Plant and Soil. 2000; 223:207-216.

9. Priyanka G, Sharma GD, Rachana R, Lal B, Joshi E. Evaluation of integrated nutrient management and plant density on productivity and profitability of rice (Oryza sativa) under system of rice intensification in mid hills of Himachal Pradesh. Indian Journal of Agronomy. 2013; 58(13):421-423.

10. Rajendran K, Raja KG, Balasubramanian R. Evaluation of crop establishment techniques and weed management practices under system of rice intensification. Madras Agricultural Journal. 2013; 100(7-9): 698-702.

11. Rajesh V, Thanunathan K. Effect of seedling age, number and spacing on yield and nutrient uptake of traditional Kambam Chamba rice. Madras Agricultural Journal. 2003; 90(1-3):47-49.

12. Rani S, Sukumari P. Root growth, nutrient uptake and yield of medicinal rice Njavara under different establishment techniques and nutrient sources. American Journal of Plant Sciences. 2013; 4:1568-1573.

13. Sharath CM. Performance of different rice (Oryza sativa (L.) varieties under alternate wetting and drying method in puddled soil. M.Sc. (Ag.) Thesis, Professor Jayashankar Telangana State Agricultural University, Hyderabad, 2017.

14. Sridevi V, Chellamuthu V. Advantages of SRI cultivation in the tail end of Cauvery delta. Journal of Crop and Weed. 2012; 8(2):40-44.

15. Uphoff N. System of Rice Intensification (SRI) for enhancing the productivity of land, labour and water. Journal of Agricultural Resource Management. 2002; $1: 43-49$
16. Vijay KP. Different duration rice (Oryza sativa L.) varieties as influenced by varied levels of nutrients application under irrigated ecology M.Sc. (Ag.) Thesis. Indira Gandhi Krishi Vishwavidyalaya, Raipur, Chhattisgarh, 2018. 